\title{
ПОРІВНЯННЯ РІЗНОВИДІВ ДОБАВОК ДЛЯ БЕТОНУ ТА ЇХ ЗАСТОСУВАННЯ У ТОНКОСТІННИХ КОНСТРУКЦІЯХ ПОКРИТТЯ
}

С.О. УЖЕГОВ

Луиякий национальный технический университет

\author{
СРАВНЕНИЕ РАЗНОВИДНОСТЕЙ ДОБАВОК ДЛЯ БЕТОНА И ИХ \\ ПРИМЕНЕНИЕ В ТОНКОСТЕННЫХ КОНСТРУКЦИЯХ ПОКРЫТИЯ
}

\author{
S. UZHEHOV \\ Lutsk National Technical University
}

\section{COMPARISON OF THE CONCRETE ADMIXTURES VARIETIES AND THEIR APPLICATION IN THIN-WALLED COVERING STRUCTURES}

\section{https://doi.org/10.36910/6775-2310-5283-2018-11-17}

Мета. Проаналізувати існуючі види хімічно активних та механічних добавок, щэо сьогодні представлені на ринку будівельних матеріалів України. Охарактеризувати їх недоліки та переваги. Особливу увагу приділити матеріалам, щзо збільшують мічність бетонів, у тому числі сталевим фібрам, щзо значно підвищують деформативність та тріщиностійкість тонкостінних конструкиій покриття у формі гіперболічного параболоїда.

Методика. Під час проведення дослідження використовувались передбачені діючими державними стандартами методи, які дозволяють визначити механічні властивості залізобетонних та сталефібробетонних оболонок для тонкостінних покриттів у формі гіперболічного параболоїда.

Результати. Встановлено, щуо сьогодні на ринку будівельних матеріалів України представлена значна кількість різноманітних хімічно активних добавок, пластифікаторів, пігментів для забарвлення, деактиваторів, сповільнювачів та прискорювачів для бетонної сумімі, протиморозних добавок. Під час проведення досліджень встановлено, щуо при введені в бетон сталевих фібр, значно збільшується його жорсткість, щзо в свою чергу призводить до підвищення деформативності від дії навантажень та тріщиностійкості сталефібробетону, як матеріалу. Відповідно, тонкостінні оболонки покриттів зі сталефібробетону у формі гіперболічного параболоїда мають кращі фізико-механічні характеристики в порівнянні з аналогічними оболонками з класичних бетонів. Тому термін їх експлуатації значно підвищується.

Наукова новизна. Встановлено вплив сталевої фібри на тріщиностійкість, деформативність та несучу здатність тонкостінних оболонкових покриттів у формі гіперболічного параболоїда. 
Практична значимість. Розроблена конструкиія тонкостінної оболонки покриття y формі гіперболічного параболоїда, щзо виготовлена зі сталефібробетону, може використовуватися під час проектування та будівництва великопролітних об'єктів 3 меншими затратами матеріалів $і$ коштів.

Ключові слова: оболонка, покриття, СФБ, сталефібробетон, тріщиностійкість, деформативність, несуча здатність.

Постановка проблеми у загальному вигляді та ії зв'язок із важливими науковими чи практичними завданнями. Зі збільшенням обсягів введення в експлуатацію нетипових будівельних об'єктів можна зробити висновок, що проектування та будівництво складних інженерних споруд із енергоефективних i безпечних конструкцій та матеріалів $\epsilon$ актуальним завданням сьогодення. Проведення дослідження в даному напрямку, відповідно $\epsilon$ перспективним розвитком науки про впровадження нових будівельних конструкцій.

У будівництві застосовуються різноманітні тонкостінні конструкції покриття, що виготовляються на основі бетону. Такі конструктивні елементи здатні перекривати великі площі без проміжних опор. Завдяки цій особливості, тонкостінні конструкції покриття (оболонки) доцільно використовувати на виробничих підприємствах 3 великогабаритним устаткуванням, спортивних комплексах, критих ринках, вокзалах, павільйонах та ін. Ці конструкції потребують значно менших витрат будівельних матеріалів порівняно 3 традиційними лінійними елементами будівлі (фермами, балками, плитами перекриття) i, відповідно, мають меншу власну вагу [1].

Аналіз останніх досліджень, у яких започатковано вирішення проблеми. Дані тонкостінні конструкції перебувають під дією статичних та динамічних навантажень. Через це використання бетону та умови його роботи в тонкостінних конструкціях ставлять завдання пошуку способів підвищення тріщиностійкості, ударної міцності, морозостійкості, легкоукладальності та інших показників. Оптимальним рішенням в цьому напрямку є застосування різноманітних добавок до бетонної суміші. Останні дослідження даної тематики описані в монографії [2], де наведені експериментально-теоретичні обгрунтування можливості виробництва високоміцних швидкотверднучих бетонів і фібробетонів з використанням пластифікаторів.

Цілі статті. Цілями статті $є$ аналіз існуючих видів хімічно активних та механічних добавок, що сьогодні представлені на ринку будівельних матеріалів України та опис їх недоліків та переваг.

Об’скт дослідження. Об'єктом дослідження є тонкостінна оболонка покриття у формі гіперболічного параболоїда зі сталефібробетону. 
Методи дослідження. В Україні застосування добавок до бетонів i будівельних розчинів регламентує ДСТУ В.2.7-175:2008 [3]. У країнах Свропи використовувані добавки регламентовані євростандартом EN 934-2 «Добавки для бетонів і розчинів. Вимоги й визначення». У цьому стандарті представлені основні характеристики добавок, завдяки яким можливо ідентифікувати добавки й виділити всі показники, які можуть знизити довговічність бетонів і розчинів (такі як зміст хлору, лугів, $\mathrm{pH}$ ) і підсилити корозію цементного каменю. У США область застосування добавок регламентується стандартами ASTM C 494 «Хімічні добавки для бетону» [4] і ASTM C 1017 «Хімічні добавки для виготовлення литого бетону» [5], у яких наведені властивості і переваги різних високоефективних суперпластифікаторів (СП), їхній вплив на бетон, аналізуються області застосування.

Виклад основного матеріалу дослідження 3 повним обгрунтуванням отриманих наукових результатів. B практиці будівництва України розробляються та застосовуються високотехнологічні добавки, що в тій чи іншій мірі покращують властивості бетонної суміші під певні потреби [6].

Українська компанія «Coral» випускає різноманітну кількість пластифікуючих добавок для сумішей під різними торгівельними назвами. Повітровтягуючі добавки Coral MasterКладка використовуються, в основному, для зменшення ваги конструкції, за рахунок утворення повітряних пор. Також вони забезпечують бетону кращу стійкість до протиожеледних реагентів, потребують меншу кількість води та дрібного заповнювача для суміші, підвищує міцність бетону.

Пришвидшувач твердіння бетону Coral MasterFix сприяє швидкому набору ранньої і марочної міцності, що дозволяє скоротити введення будівельних робіт в 3-4 рази. Добавка покращує товарний вигляд і зменшує розтріскування виробу.

Виробник «Hormusend» (Україна) постачає на будівельник ринок пігменти для бетонної суміші, що застосовуються для забарвлення бетону в необхідний колір при архітектурних, інженерних та естетичних вирішеннях.

Німецький виробник МTC $\mathrm{GmbH}$ реалізовує пластифікатор для підвищення довговічності бетонного елемента, що забезпечує опір руйнування бетону, викликаного стиранням, корозією арматури, хімічними речовинами, і усадочним розтріскуванням. Дана добавка застосовується для бетонів 3 високими вимогами по міцності в промисловому й цивільному будівництві, а також при будівництві гідротехнічних споруджень. Також, даний пластифікатор підвищує пластичність та легкоукладальність бетонної суміші. 
Швейцарська компанія Sika для прискорення або ж сповільнення реакції тужавлення бетону, залежно від місця застосування бетонної суміші, пропонує кілька технічних вирішень: пластифікатори Sika Plast 520 або Sika Rapid 2.1.

Сповільнювач бетонної суміші або деактиватор бетону Sika Plast 520 знижує хімічний процес гідратації цементу, через що суміш може контрольований період часу не тверднути. Використовуються суміші для виробництва товарного бетону, що дає можливість транспортування бетону протягом трьох годин і більше. Також, добавку застосовують при зведенні масивних монолітних конструкцій із метою зниження тепловиділення при твердінні бетону.

Прискорювач твердіння бетонної суміші Sika Rapid 2.1 сприяє набору ранньої міцності бетону в 70\% за перші 24 години, і 95-100 \% міцності на третю добу. Завдяки даному пластифікатору стає можливим зняття опалубки 3 вертикальних поверхонь для фінішної обробки вже через 1-3 години.

Компанія «Релаксол» реалізує протиморозну добавку Релаксол-Антифриз FSR, яка протягом багатьох років добавки використовуються при будівництві великих об'єктів промислового й цивільного будівництва. Вона застосовується при виконанні будівельних робіт при мінусових температурах навколишнього середовища, та запобігає можливому руйнуванню зовнішніх шарів бетонних конструкцій внаслідок дії від’ємних температур.

Гідроізоляційні добавки компанії «Акватрон» проникають у пори та пустоти бетону, кристалізуються в них, створюючи бар'єр для води, при цьому додатково зміцнюють конструкцію та запобігають проступанню солей на поверхню. Одночасно, пластифікатор створює захисну плівку на поверхні свіжого бетону для утримання вологи всередині і збільшення потенціалу гідратації цементу. Це дозволяє отримувати достатню міцність та довговічність бетону.

Сьогодні основні будівельні конструкції, що в процесі своєї експлуатації піддаються значному навантаженню, виготовляють із залізобетону. Під впливом погодно-кліматичних факторів та вібраційних коливань від руху транспортних засобів на поверхні цих елементів, в процесі експлуатації, відбуваються руйнування, що призводять до утворення тріщин, вибоїн, вилущування бетону, руйнування захисного шару бетону та ін.

Одним з варіантів вирішення даної проблеми є застосування дисперсноармованого бетону в цих конструкціях. Ефективність застосування сталефібробетону (СФБ) в будівельних конструкціях може досягатися за 
рахунок зниження трудовитрат на арматурні роботи, суміщення технологічних операцій на приготування, армування, укладання та ущільнення СФБ суміші, продовження терміну експлуатації конструкцій i зниження витрат на різні види поточного ремонту.

Серед найбільш поширених видів фібр на будівельному ринку України представлені фібри, як вітчизняного так i закордонного виробництва. Українське підприємство Сітка-Захід виготовляє сталеву фібру (рис. 1), яка використовується для армування високонавантажених промислових підлог, фундаментних плит та тонкостінних конструкцій покриттів, де необхідно забезпечити жорсткість та тріщиностійкість.

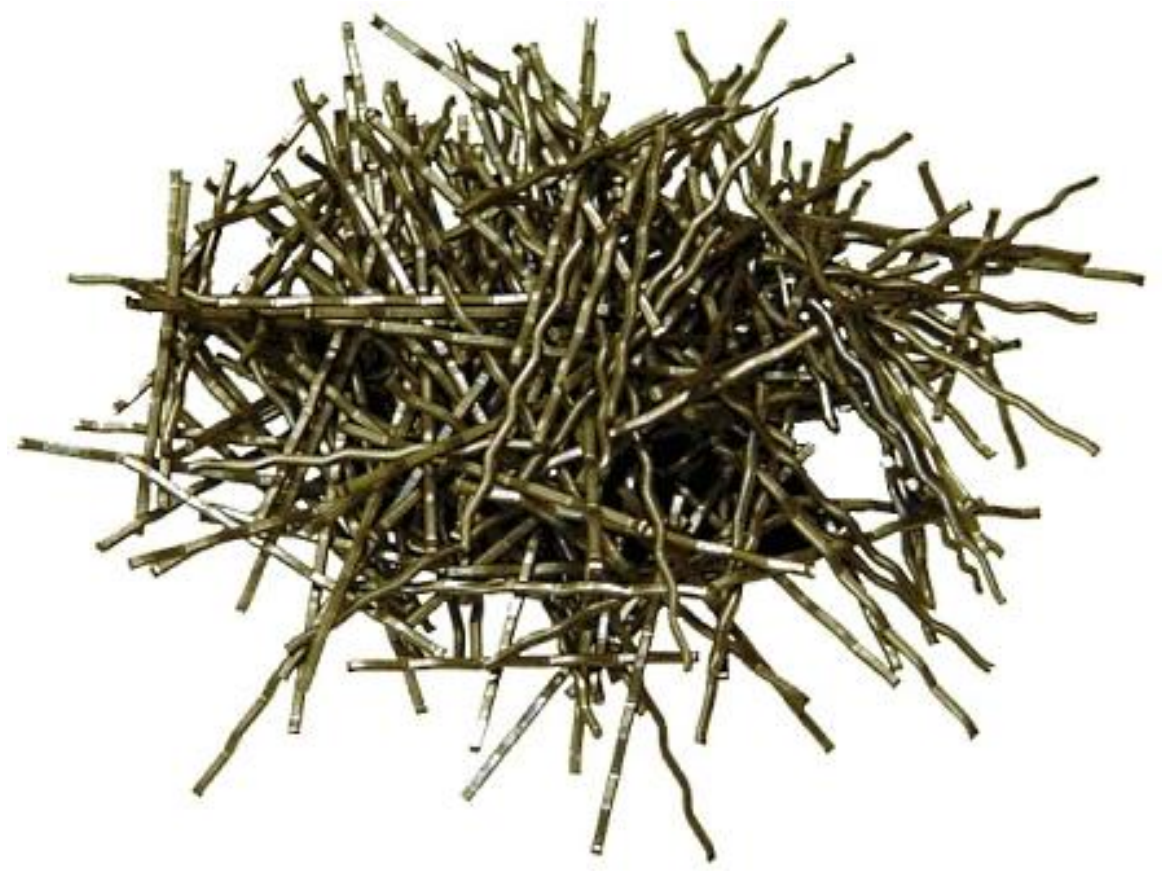

Рис. 1. Сталева фібра

Досвід використання СФБ показав, що найефективніше застосовувати цей матеріал в залізобетонних конструкціях для підвищення їх тріщиностійкості, в тонкостінних конструкціях, в спорудах, що працюють на ударні навантаження (в покриттях аеродромів та автомобільних доріг, в сейсмостійких конструкціях, хвилерізах, молах, фортифікаційних спорудах, палях, трубах, лотках) [9 - 11].

Варто відмітити, під час виконання наукових лабораторних досліджень $[12,13]$ було застосовано сталеві фібри аналогічні, що представлені на рис 4. Отримані результати підтвердили значний ефект від додавання фібр до матриці-бетону та підвищення тріщиностійкості та деформативності. 
Сьогодні також значна увага науковців приділена застосуванню фібр в штучних спорудах із залізобетону на автомобільних дорогах [14].

Висновки та перспективи подальших досліджень. Автором статті, під час проведення лабораторних випробувань в роботі [1] отримано значний позитивний ефект та підвищення міцності, несучої здатності, жорсткості, тріщиностійкості тонкостінної оболонки покриття у вигляді гіперболічного параболоїда (рис. 2), що була виготовлена з сталефібробетону в порівнянні 3 аналогічною конструкцією, що була виготовлена 3 залізобетону (армоцементу).

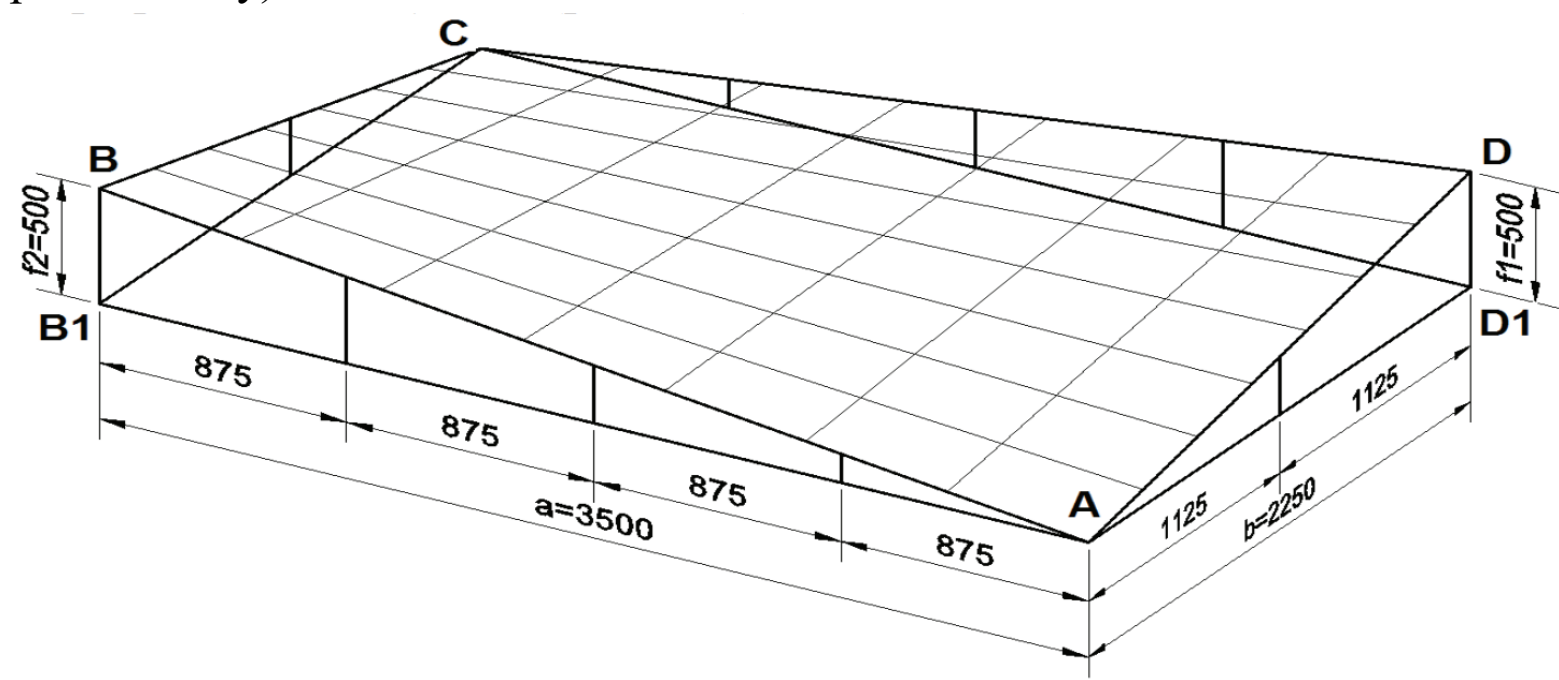

Рис. 2. Схематичне зображення тонкостінної оболонки покриття у вигляді гіперболічного параболоїда

Проведення досліджень дисперсно-армованих бетонів $є$ актуальним та перспективним напрямком науки про будівельні конструкції.

У даній статті проаналізовано найбільш поширені хімічно активні добавки для бетонів та будівельних розчинів, що представлені в Україні. Велика увага приділена застосуванню сталевих фібр в тонкостінних конструкціях.

\section{Література}

1. Ужегов С.О. Визначення оптимальних розмірів конструктивних елементів сталефібро-бетонної конструкції покриття у формі гіперболічного параболоїда / C.О. Ужегов, Р.В. Пасічник, О.В. Андрійчук // Ресурсоекономні матеріали, конструкції, будівлі та споруди: Збірник наукових праць - Рівне: НУВГП, 2014. - Випуск 29. - С. 506 - 511.

2. Дворкін Л.Й., Бабич Є.М., Житковський В.В. та ін. Високоміцні швидкотверднучі бетони та фібробетони: монографія. - Рівне: НУВГП, 2017. - 331 с.

3. ДСТУ-Н Б В.2.7-175:2008. Будівельні матеріали. Настанова щодо застосування хімічних добавок у бетонах і будівельних розчинах. 
4. ASTM C494 / C494M - 17. Standard Specification for Chemical Admixtures for Concrete.

5. ASTM C1017 / C1017M - 13e1. Standard Specification for Chemical Admixtures for Use in Producing Flowing Concrete.

6. Ткачук В.В. Товарознавча оцінка екологічних показників будівельних матеріалів / В.В. Ткачук, Д. В. Дзюбинський // Екологічні нотатки. - № 3. - Луцьк: РВВ Луцький НТУ. 2016 - С. 53-58.

7. Гивлюд М.M. Теплофізичні характеристики вогнезахищеного бетону покриттями на основі наповненого поліалюмосилоксану [текст] / М. Гивлюд, І. Смченко, О. Передрій // Вісник НУ «Львівська політехніка». - 2010. - № 662 «Теорія і практика будівництва». - С. $126-131$.

8. Андрійчук О.В. Виготовлення придорожніх лотків водовідводу зі сталефібробетону / О.В. Андрійчук, І.М. Ясюк// Наукові нотатки: збірник наукових праць Луцьк: Луцький НТУ, 2014. - Випуск 45. - С. 7 - 14

9. Андрійчук О.В. Сталефібробетонні безнапірні труби / О.В. Андрійчук, Є.М. Бабич // Монографія. - Луцьк: РВВ Луцького НТУ, 2012. - 150 с.

10. Бабич Є.M. Проектування та виготовлення безнапірних труб із сталефібробетону / Є.М. Бабич, О.В. Андрійчук // Рекомендації. - Луцьк: ЛНТУ, 2012. - С. 32.

11. Бабич С.М. Про доцільність використання сталефібробетону для виготовлення безнапірних труб / С.М. Бабич, О.В. Андрійчук // Ресурсоекономні матеріали, конструкції, будівлі та споруди: Збірник наукових праць - Рівне: НУВГП, 2009. - Випуск 18. - С. 119 126.

12. Babych, E.M., Andriichuk, O.V. Strength of Elements with Annular Cross Sections Made of Steel-fiber-Reinforced Concrete Under One-Time Loads / E.M. Babych, O.V. Andriichuk // Materials Science, Vol. 52, No. 4, New York - 2017, p. 509 - 513.

13. Андрійчук О.В. Робота і розрахунок елементів кільцевого перерізу при дії повторних навантажень: Автореф. дис... канд. техн. наук: 05.03.21 / О.В. Андрійчук Львів, 2011. - 24 с.

14. Дорошенко О. Дисперсно-армований бетон - надійний та ефективний матеріал для транспортного будівництва / О. Дорошенко, Ю. Дорошенко, Н. Чиженко, К. Гудименко // Транспортное строительство Украины. - 2007. - №1 (5). - С. 16 - 19.

Цель. Проанализировать существующие виды химически активных и механических добавок, которые сегодня представлены на рынке строительных материалов Украины. Охарактеризовать их недостатки и преимущества. Особое внимание уделить материалам, что увеличивает прочность бетонов, в том числе стальным фибрам, что значительно повышают деформативность и трещиностойкость тонкостенных конструкиий покрытия в форме гиперболического параболоида.

Методика. Во время проведения исследования использовались предусмотренные действуюшими государственными стандартами методы, которые позволяют определить механические свойства железобетонных и сталефибробетонных оболочек для тонкостенных покрытий в форме гиперболического параболоида.

Результаты. Установлено, что сегодня на рынке строительных материалов Украинь представлено значительное количество разнообразных химически активных добавок, пластификаторов, пигментов для окраски, деактиваторов, замедлителей и ускорителей для бетонной смеси, противоморозных добавок. Во время проведения исследований установлено, что при введении в бетон стальных фибр, значительно увеличивается его жесткость, что в свою очередь приводит $\kappa$ повышению деформативности от действия нагрузок и трещинностойкости сталефибробетона, как 
материала. Соответственно, тонкостенные оболочки покрытий из сталефибробетона в форме гиперболического параболоида имеют лучшие физико-механические характеристики по сравнению с аналогичными оболочками из классических бетонов. Поэтому срок их эксплуатации значительно повышается.

Научная новизна. Установлено влияние стальной фибры на трещиностойкость, деформативность и несущую способность тонкостенных оболочечных покрытий в форме гиперболического параболоида.

Практическая значимость. Разработана конструкиия тонкостенной оболочки покрытия в форме гиперболического параболоида, что изготовлена из сталефибробетона, может использоваться во время проектирования и строительства большепролетных объектов с меньшими затратами материалов и средств.

Ключевые слова: оболочка, покрытие, СФБ, сталефибробетон, трещчиностойкость, деформативность, несущая способность.

Purpose. Analysis of existing types of mechanical and chemical admixtures, which are present on the market of modern building materials in Ukraine. Describing their advantages and disadvantages. Paying particular attention to materials, that increase the strength of the concrete, including steel fibers that significantly increase the deformation and fracture of thin-walled covering structures shaped like a hyperbolic paraboloid.

Methodology. During conducting of the research it was used acting regulatory methods of national standards, which allow to determine the mechanical properties of reinforced concrete and steel fiber reinforced concrete thin-walled covering structures shaped like a hyperbolic paraboloid.

Findings. Building materials that are available on the market in Ukraine are represented via large variety of chemical admixtures, plasticizers, pigments for coloring, retarders and accelerators of the concrete mix, antifreeze admixtures. During research it is established that adding of steel fibers to the concrete significantly increases its rigidity, which in turn leads to an increase of deformation from the loads and fracture toughness of steel fiber reinforced concrete. Accordingly, a thin shell covering structures made of steel fiber reinforced concrete shaped like a hyperbolic paraboloid have the best physical-mechanical characteristics in comparison with similar shells made of the classical concrete. Therefore, their life time is significantly increased.

Originality. It was identified the influence of steel fibers on the fracture toughness, deformability and bearing capacity of thin shell covering structures shaped like a hyperbolic paraboloid.

The practical value. It was developed the design of thin shell covering structure shaped like a hyperbolic paraboloid, which is made of steel fiber reinforced concrete. It can be used during the design and construction of large-span objects with lower costs of materials and resources.

Keywords: shell, covering, SFRC, steel fiber reinforced concrete, fracture toughness, deformability, bearing capacity.

Рекомендовано до публікаиії д.т.н. професором Луцьького НТУ Шваб'юком В.І. Дата надходження в редакиію 30.01.2018 